\title{
A Study on the Attributes of Effective English Lecturers as Perceived by EFL Learners: The Case of Indonesia
}

\author{
Heri Mudra \\ State Islamic Institute of Kerinci \\ Correspondence concerning this article should be addressed to Heri Mudra, English Language \\ Department, State Islamic Institute of Kerinci, Kerinci, Provinsi Jambi, Indonesia, 37112. \\ E-mail: mudraheri@gmail.com
}

\begin{abstract}
This study aims to uncover the attributes of effective English lecturers and any significant differences between male and female EFL learners in determining the attributes of effective EFL lecturers. The study utilized a descriptive study design by asking 52 EFL learners to be respondents by filling in a questionnaire. The results depicted that the attributes associated with the 'rapport' category were friendliness, relationship, experiences, positive attitudes, and sense of humour. An independent t-test also showed there was no significant difference between male and female EFL learners in determining these attributes. The attributes of the 'delivery' category included enthusiasm, clarity, correction, and encouragement. The attributes of the 'fairness' category included treatment and standard. The attributes of the 'knowledge and credibility' category included proficiency and knowledge. The attributes of the 'organization and preparation' category included preparation, course contents, objectives, and materials. As for the implications, the attributes enable EFL lecturers to figure out various strategies for teaching English. Moreover, it is advantageous for EFL learners in that they can adjust their learning styles with the attributes.
\end{abstract}

Keywords: attributes of effective EFL lecturers, English as a Foreign Language (EFL) learners, EFL lecturer style and competence

English as a Foreign Language (EFL) learning in Indonesia has become a more popular activity for learners. Due to the importance of communicating in a global context, EFL learners strive for better and deeper English knowledge and skills. To achieve such goals, EFL teachers play a prominent role in ensuring that learners become skilled users of English both formally and informally. Many EFL teachers are able to act as better models for their learners. Moreover, those EFL teachers are highly competent in teaching English to the EFL learners.

EFL learners who are motivated to become skilled English users have to be aware of which teachers are competent in teaching English and which teachers are not competent. In the Indonesian context, EFL teachers are expected to be competent in teaching English. According to A.S. Canagarajah, teachers whose language is not English and who tend to teach English properly do not have to be like a native speaker (1999).

A. Yilmaz (2011) investigated students' perceptions toward effective teachers in a Turkish university, revealed that the characteristics of effective teachers include those who are affectionate, warm, generous, earnest, hospitable, inspiring, enthusiastic, and active. Another study, Chen and Lin (2009), summed up the 'effectiveness' of teachers being mainly related to their personality and their relationship with learners, as opposed to their instructional competence. Moreover, they revealed that effective teachers should be energetic, affectionate, objective, deferential, and kind.

Koc (2012) explored the characteristics of good language teachers as perceived by students. The study revealed that affective characteristics play an important role in shaping good English language teachers. These characteristics include: being patient with what the students do, inspiring the students, fulfilling the students' needs, maintaining a good relationship with them, and establishing contact with their parents. The students surveyed were elementary, junior, and high school students categorized by level. Another study on effective English language teachers conducted by Wichadee (2010) found that there are four categories associated with effective English language teaching: English proficiency, pedagogical knowledge, organization and communication skills, 
and socio-affective skills.

The attributes of effective EFL teachers were adapted by Faranda and Clarke (2004). They organized the attributes into five categories: rapport, delivery, fairness, knowledge and credibility, and organization and preparation. Rapport is concerned with how a teacher becomes friendly, affable, vehement, and approachable. Delivery is concerned with how a teacher delivers a lesson with particular strategies or techniques. This includes enthusiasm, methods, correction, encouragement, questioning, and motivation. Fairness focuses on how a teacher treats learners, which includes treatment, examination, grading, and hard work. Knowledge and credibility focus on intelligence, qualification, and mastery. Organization and preparation focus on preparation, comprehension, and delivery materials (Faranda \& Clark, 2004, p. 279).

The focus of the present study was to apply Faranda and Clarke's (2004) model to identify the attributes of effective English lecturers as perceived by EFL learners. To this end, two research questions were proposed:

1) What are the attributes of effective English lecturers as perceived by EFL learners in an Indonesian context?

2) Are there any significant differences in the attributes of effective English lecturers between male and female EFL learners in an Indonesian context?

\section{Methods}

\section{Design of the study}

A descriptive study design was employed in this research. Descriptive research is a kind of research that uses an instrument such as a scale or a questionnaire and particular samples during data collection (Robson, 1993). More specifically, data in descriptive research are collected by undertaking the steps of administering and collecting, categorizing, estimating, and analyzing the data (Glass \& Hopkins, 1984).

\section{Participants}

This study was conducted by asking fifty-two senior EFL learners to fill in a questionnaire. The participants consisted of EFL learners who were learning English in a public institute in Kerinci, Indonesia. They consisted of $22(42.3 \%)$ male and 30 (57.6\%) female learners. A convenience sampling technique was employed to select the participants for this study. This sampling technique enabled the researcher to select the participants due to their readiness, willingness, availability, and accessibility (Dörnyei, 2007).

\section{Data collection tool}

This study used a modified questionnaire as the instrument for collecting the data. The Effective English Lecturers questionnaire was developed by Faranda \& Clarke (2004) and modified by Barnes (2008) to measure the characteristics of effective English lecturers. The Effective English Lecturers questionnaire consists of 42 items using a 7-point Likert scale ranging from 1 (strongly agree) to 7 (strongly disagree). The questionnaire consists of five categories which include rapport, delivery, fairness, knowledge and credibility, and organization and preparation (Barnes, 2008). The result of pilot studies revealed that the Cronbach alpha of the questionnaire is .87 , which proves that the questionnaire has high rate of reliability.

\section{Data analysis}

The purpose of the data analysis was to estimate the Frequencies, Means, and Standard Deviation (SD) of the attributes of effective English lecturers and find out significant differences between male and female EFL learners' choices of the attributes. As the results of normality tests proved that the data were normal, an independent t-test was employed. The data were estimated by dividing them into each category employed by Faranda and Clarke (2004): Rapport, Delivery, Fairness, Knowledge and Credibility, and Organisation and Preparation. The quantitative data were analyzed by using SPSS 16 .

\section{Results}

\section{The characteristics of EFL lecturers based on each category of the questionnaire}

The following table shows frequency details in terms of percentages of learners' preferences for effective English lecturers.

Table 1 depicted levels of percentages viewed by the EFL learners towards characteristics of effective English lecturers' rapport items. As for the first item "are friendly," more learners (53.8\%) slightly agreed that their English lecturers considered them as partners in the classroom. The smallest number (3.8\%) of learners did not find their lecturers friendly to them. The learners (50\%) believed that their lecturers have developed good relationships with them. Having a good relationship supports each learner to learn English in better ways. The third item "share personal experiences" can be an additional prize for EFL learners as their lecturers' personal experiences become a good example for them to follow. A larger number of 
Table 1

Frequencies, Means, and Standard Deviations of Rapport category

\begin{tabular}{lccccccccc}
\hline \multicolumn{1}{c}{ Items } & \multicolumn{4}{c}{ Frequencies (\%) } & \multicolumn{3}{c}{ M } & \multirow{2}{*}{ SD } \\
\cline { 2 - 7 } & $\mathbf{1}$ & $\mathbf{2}$ & $\mathbf{3}$ & $\mathbf{4}$ & $\mathbf{5}$ & $\mathbf{6}$ & $\mathbf{7}$ & & \\
\hline 1.are friendly & 7.7 & 9.6 & 53.8 & 9.6 & 3.8 & 11.5 & 3.8 & 3.42 & 1.473 \\
2.develop good relationship with students & 11.5 & 19.2 & 50 & 5.8 & 7.7 & 1.9 & 3.8 & 3.00 & 1.358 \\
3.share personal experiences & 26.9 & 48.1 & 9.6 & 5.8 & 5.8 & 1.9 & 1.9 & 2.29 & 1.362 \\
4.care about students & 1.9 & 5.8 & 9.6 & 50 & 19.2 & 7.7 & 5.8 & 4.25 & 1.219 \\
5.are patient & 0 & 7.7 & 7.7 & 7.7 & 46.2 & 21.2 & 9.6 & 4.94 & 1.305 \\
6.listen to students & 5.8 & 9.6 & 11.5 & 7.7 & 48.1 & 11.5 & 5.8 & 4.40 & 1.537 \\
7.have a positive attitude in general & 23.1 & 46.2 & 17.3 & 5.8 & 1.9 & 1.9 & 3.8 & 2.38 & 1.402 \\
8.have charisma & 5.8 & 5.8 & 5.8 & 51.9 & 9.6 & 11.5 & 9.6 & 4.27 & 1.483 \\
9.understand the students' English education background & 3.8 & 21.2 & 51.9 & 3.8 & 7.7 & 3.8 & 7.7 & 3.33 & 1.491 \\
10.understand the different student levels & 3.8 & 9.6 & 53.8 & 7.7 & 7.7 & 9.6 & 7.7 & 3.65 & 1.532 \\
11.have a sense of humour & 5.8 & 11.5 & 55.8 & 1.9 & 11.5 & 7.7 & 5.8 & 3.48 & 1.502 \\
\hline
\end{tabular}

Note: $1=$ Strongly agree, $2=$ Agree, $3=$ Slightly Agree, $4=$ No Feelings, $5=$ Slightly Disagree, $6=$ Disagree, $7=$ Strongly Disagree

learners (48.1\%) got more personal experiences from their lecturers and they found the experiences useful for their English learning. A number of learners (50\%) doubted that their lecturers cared about their English learning.Furthermore, nearly half of the learners (46.2\%) did not agree that their English lecturers were patient with them.

English lecturers might find more problems during their teaching. One of the problems was related to what their learners experienced. The sixth item revealed that the learners (48.1\%) found their English lecturers did not accept their requests or complaints. Fortunately, more learners (46.2\%) believed that their lecturers have positive attitudes toward their learning. Another item (51.9\%) showed that the learners were doubtful that the lecturers come to the classroom with charisma. The ninth item (51.9\%) proved that the lecturers managed their teaching by considering learners' educational backgrounds. This can be helpful for learners with different English abilities. Moreover, more lecturers (53.8\%) knew how to face learners with different levels. As for the last item in the rapport category, lecturers with a better sense of humour were considered more positive for teaching English. The learners (55.8\%) found that lecturers who were able to give some humour could break any kind of pressure during difficult tasks.

The lowest score, which revealed positive views toward the characteristics of English lecturers, was the item "share personal experiences" $(\mathrm{M}=2.29$ \& $\mathrm{SD}=1.362$ ). The participants were able to see that their lecturers shared any experiences they had when they delivered a lesson. Such experiences were deemed helpful contributions for them as they could learn more good things from those experiences. The English learners reported that there were positive attributesshowed by their lecturers in the classroom $(\mathrm{M}=2.38 \& \mathrm{SD}=1.402)$. The lecturers developed good relationship with their learners $(\mathrm{M}=3.00 \& \mathrm{SD}=1.358)$.

The Delivery category consists of item 12 - item 28. Each of the items describes the process of delivery in the classroom. In item 12, it is seen that English lecturers were enthusiastic about the teaching and learning process. A bigger number of EFL learners (57.7\%) agreed that their EFL classroom was full of enthusiasm, which is the most basic motivation for both teachers and learners. However, the result of item 13 showed that the learners were doubtful about whether their lecturers explained any English lessons clearly (61.5\%). A small number of learners (13.5\%) got better explanations from their lecturers than expected. Even though some learners were still in doubt about the explanation, more learners $(55.8 \%)$ were sure that good examples given by their lecturers replaced unclear explanations. Moreover, the lecturers did not use different teaching methods during the delivery (36.5\%). Some of the learners (23.1\%) still hoped their lecturers would use more teaching methods in their lessons.

Based on the result of item 16, it was revealed that the lecturers managed to use both Indonesian and English properly (23.1\%). They used Indonesian as the mother tongue selectively (19.2\%). This helps learners with low English aptitudes adjust themselves to an English class. To support the learners increasing their English skills, some direct actions were performed. Item 17 showed that most learners (59.6\%) got written correction from their lecturers when they wrote any sentence in English. The lecturers also corrected the learners' oral production when they used English either in a discussion or in a question-answer session. 
Table 2

Frequencies, Means, and Standard Deviations of Delivery category

\begin{tabular}{|c|c|c|c|c|c|c|c|c|c|}
\hline \multirow{2}{*}{ Items } & \multicolumn{7}{|c|}{ Frequencies (\%) } & \multirow{2}{*}{$\mathbf{M}$} & \multirow{2}{*}{ SD } \\
\hline & 1 & 2 & 3 & 4 & 5 & 6 & 7 & & \\
\hline 12.are enthusiastic about EFL lecturing & 13.5 & 57.7 & 11.5 & 7.7 & 3.8 & 3.8 & 1.9 & 2.50 & 1.336 \\
\hline 13.give clear explanations & 5.8 & 13.5 & 1.9 & 61.5 & 7.7 & 7.7 & 1.9 & 3.83 & 1.279 \\
\hline 14.use good examples & 7.7 & 17.3 & 55.8 & 1.9 & 7.7 & 7.7 & 1.9 & 3.15 & 1.349 \\
\hline 15.use a variety of teaching methods & 3.8 & 5.8 & 9.6 & 17.3 & 23.1 & 36.5 & 3.8 & 4.75 & 1.480 \\
\hline 16.use Indonesian selectively & 17.3 & 19.2 & 23.1 & 13.5 & 11.5 & 11.5 & 3.8 & 3.33 & 1.757 \\
\hline 17.correct writing errors & 9.6 & 13.5 & 59.6 & 3.8 & 1.9 & 9.6 & 1.9 & 3.12 & 1.353 \\
\hline 18.correct speaking errors & 0 & 0 & 100 & 0 & 0 & 0 & 0 & 3.00 & .000 \\
\hline 19.teach grammar & 13.5 & 23.1 & 26.9 & 11.5 & 11.5 & 9.6 & 3.8 & 3.29 & 1.673 \\
\hline 20.use group work & 9.6 & 19.2 & 30.8 & 9.6 & 13.5 & 9.6 & 7.7 & 3.58 & 1.742 \\
\hline 21.encourage student participation in class & 5.8 & 11.5 & 50 & 13.5 & 9.6 & 9.6 & 0 & 3.38 & 1.270 \\
\hline 22.encourage the participation of students with low confidence & 1.9 & 13.5 & 57.7 & 5.8 & 11.5 & 5.8 & 3.8 & 3.44 & 1.305 \\
\hline 23.talk slowly in English & 3.8 & 3.8 & 5.8 & 3.8 & 67.3 & 7.7 & 7.7 & 4.81 & 1.269 \\
\hline 24.use easy words & 5.8 & 63.5 & 11.5 & 5.8 & 7.7 & 5.8 & 0 & 2.63 & 1.284 \\
\hline 25.use questions frequently & 3.8 & 5.8 & 7.7 & 65.4 & 7.7 & 7.7 & 1.9 & 3.98 & 1.111 \\
\hline 26.ask questions then wait for volunteers to answer & 3.8 & 5.8 & 5.8 & 67.3 & 7.7 & 7.7 & 1.9 & 4.00 & 1.103 \\
\hline 27.ask individual students to answer questions & 1.9 & 1.9 & 17.3 & 58 & 48.1 & 15.4 & 9.6 & 4.81 & 1.329 \\
\hline 28.give students plenty of time to answer questions & 5.8 & 9.6 & 15.4 & 5.8 & 59.6 & 3.8 & 0 & 4.15 & 1.349 \\
\hline
\end{tabular}

Note: $1=$ Strongly agree, 2= Agree, 3= Slightly Agree, 4= No Feelings, 5= Slightly Disagree, 6= Disagree, 7= Strongly Disagree

All of the learners (100\%) agreed that the speaking correction was beneficial for their oral skills. In line with that, the lecturers (26.9\%) provided good grammatical examples and the learners were asked to use such grammatical rules in their writing and speaking activities.

One of the most popular methods as experienced by the learners (30.8\%) was group work. Group work was believed to be effective for the learners as they were often asked to work in a team. Each learner collaborated with other group members by asking them to work with one subtopic. The purpose of this technique was to let them participate in the lesson. Most learners (50\%) were encouraged to take part in a discussion during a lesson. Furthermore, more learners with low confidence $(57.7 \%)$ were involved in class discussions, which motivated them to do so in other English classes. What made the learners worried about English class was the use of fast English. The learners $(67.3 \%)$ could not understand a topic when the lecturers spoke faster than they expected. The good news was seen in item 24 in which the learners (63.5\%) deemed it enjoyable for them to listen to the lecturers' lectures as they used easy words.

To grab learners' attention, questioning techniques could be more effective. Item 25 showed that the lecturers (65.4\%) did not ask questions to the learners frequently. The learners (67.3\%) were doubtful that their lecturers offered sufficient time for them to think of any answer for the questions. The questions were

Table 3

Frequencies, Means, and Standard Deviations of Fairness category

\begin{tabular}{lccccccccc}
\hline \multicolumn{1}{c}{ Items } & \multicolumn{4}{c}{ Frequencies (\%) } & \multicolumn{3}{c}{ M } & \multirow{2}{*}{ SD } \\
\cline { 2 - 7 } & $\mathbf{1}$ & $\mathbf{2}$ & $\mathbf{3}$ & $\mathbf{4}$ & $\mathbf{5}$ & $\mathbf{6}$ & $\mathbf{7}$ & & \\
\hline 29.treat all students fairly & 5.8 & 13.5 & 7.7 & 55.8 & 5.8 & 5.8 & 5.8 & 3.83 & 1.396 \\
30.prepare students well for examinations & 11.5 & 13.5 & 5.8 & 3.8 & 55.8 & 5.8 & 3.8 & 4.12 & 1.676 \\
31.give students clear grading guidelines & 3.8 & 9.6 & 9.6 & 3.8 & 53.8 & 9.6 & 9.6 & 4.62 & 1.510 \\
32.require students to work hard during class & 7.7 & 13.5 & 5.8 & 7.7 & 42.3 & 15.4 & 7.7 & 4.40 & 1.706 \\
33.require students to do homework & 3.8 & 5.8 & 67.3 & 5.8 & 9.6 & 3.8 & 3.8 & 3.38 & 1.223 \\
\hline
\end{tabular}

Note: $1=$ Strongly agree, 2= Agree, 3= Slightly Agree, 4= No Feelings, 5= Slightly Disagree, 6= Disagree, 7= Strongly Disagree 
never addressed to a particular learner. So, the learners (48.1\%) did not believe they were expected to answer. The fact was, based on the item 28 , the learners needed more time to think of an answer (59.6\%).

As for the most positive views of the characteristics of effective English lecturers, it can be seen from the lowest scores of the Means and SD. The first positive view was "are enthusiastic about EFL lecturing" $(\mathrm{M}=2.50 \& \mathrm{SD}=1.336)$. This positive view was interconnected with other characteristics because of how learners can be more motivated. Another positive view was "use easy words" ( $\mathrm{M}=2.63 \& \mathrm{SD}=1.248)$. The item "correct speaking errors" was the most positive view as all of the learners $(\mathrm{M}=3.00 \& \mathrm{SD}=.000)$ got their speaking corrected.

The third category, fairness, was explained in the above table. Fairness is about how lecturers see their learners as objectively as possible. The item 29 "treat all students fairly" was seen as a very important item by which learners were able to motivate themselves to interact with their lecturers more professionally. The learners $(55.8 \%)$ were in doubt whether their lecturers treated them fairly. In this case, some learners (13.5\%) believed that they got proper treatment from their lecturers. Improper treatment was proved in item 30 , which revealed that most learners (55.8\%) did not get proper and clear instructions to prepare for their exams. Moreover, the guidelines of the scoring system were to given to many of the learners (53.8\%). The learners $(42.3 \%)$ were not motivated to work more seriously during class. Fortunately, the lecturers (67.3\%) asked each learner to undertake practical and useful activities as homework.

Two positive views of the characteristics of effective English lecturers were identified. Some learners were treated fairly, but others were not $(\mathrm{M}=3.83$ \& $\mathrm{SD}=$ 1.396). Another positive view was that learners were required to do homework $(\mathrm{M}=3.38 \& \mathrm{SD}=1.223)$. Other items depicted negative views.

In the knowledge and credibility category, the first item showed that the learners (15.4\%) believed that their English lecturers were qualified for teaching English. More learners (32.7\%) were doubtful with their lecturers' qualifications. A small number of learners $(11.5 \%)$ did not see them as qualified lecturers. Fortunately, most of the learners (67.3\%) believed that their lecturers were knowledgeable in grammar. This means that most lecturers used grammatically-correct utterances during their English utterances. A smaller number of learners (7.7\%) did not trust their lecturers' grammar knowledge. The last item revealed the same belief. The learners (61.5\%) found that their lecturers were highly qualified when using vocabulary. Not many learners $(9.6 \%)$ disagreed with this.

The lowest score $(\mathrm{M}=3.12 \& \mathrm{SD}=1.182)$ was concerned with a strong ability to use grammar. It was followed by item 36 , which focused on a strong ability to use vocabulary. The only negative view was good qualifications for lecturing $(\mathrm{M}=3.58 \& \mathrm{SD}=1.637)$.

The table above describes organizations and

Table 4

Frequencies, Means, and Standard Deviations of Knowledge and Credibility category

\begin{tabular}{|c|c|c|c|c|c|c|c|c|c|}
\hline \multirow{2}{*}{ Items } & \multicolumn{7}{|c|}{ Frequencies (\%) } & \multirow{2}{*}{$\mathbf{M}$} & \multirow{2}{*}{ SD } \\
\hline & 1 & 2 & 3 & 4 & 5 & 6 & 7 & & \\
\hline 34.are well qualified for EFL lecturing & 13.5 & 15.4 & 13.5 & 32.7 & 11.5 & 9.6 & 3.8 & 3.58 & 1.637 \\
\hline 35.have a good knowledge of grammar & 7.7 & 9.6 & 67.3 & 1.9 & 7.7 & 3.8 & 1.9 & 3.12 & 1.182 \\
\hline 36.have a good knowledge of vocabulary & 3.8 & 11.5 & 61.5 & 3.8 & 9.6 & 7.7 & 1.9 & 3.35 & 1.266 \\
\hline
\end{tabular}

Note: $1=$ Strongly agree, $2=$ Agree, $3=$ Slightly Agree, 4= No Feelings, $5=$ Slightly Disagree, $6=$ Disagree, $7=$ Strongly Disagree

Table 5

Frequencies, Means, and Standard Deviations of Organization and Preparation category

\begin{tabular}{|c|c|c|c|c|c|c|c|c|c|}
\hline \multirow{2}{*}{ Items } & \multicolumn{7}{|c|}{ Frequencies (\%) } & \multirow{2}{*}{$\mathbf{M}$} & \multirow{2}{*}{ SD } \\
\hline & 1 & 2 & 3 & 4 & 5 & 6 & 7 & & \\
\hline 37.are well prepared every lecture & 3.8 & 7.7 & 61.5 & 5.8 & 5.8 & 11.5 & 3.8 & 3.52 & 1.393 \\
\hline 38.provide a syllabus detailing course content week by week & 3.8 & 13.5 & 57.7 & 11.5 & 9.6 & 1.9 & 1.9 & 3.23 & 1.113 \\
\hline 39.explain instructional methods to the class & 5.8 & 11.5 & 9.6 & 46.2 & 13.5 & 9.6 & 3.8 & 3.94 & 1.406 \\
\hline 40.tell students the lesson objectives each lesson & 5.8 & 15.4 & 46.2 & 7.7 & 15.4 & 5.8 & 3.8 & 3.44 & 1.434 \\
\hline 41.stick to the syllabus & 3.8 & 11.5 & 13.5 & 3.8 & 53.8 & 9.6 & 3.8 & 4.37 & 1.456 \\
\hline 42.make their own supplemental material & 11.5 & 63.5 & 9.6 & 1.9 & 5.8 & 5.8 & 1.9 & 2.52 & 1.407 \\
\hline
\end{tabular}

Note: $1=$ Strongly agree, $2=$ Agree, $3=$ Slightly Agree, $4=$ No Feelings, $5=$ Slightly Disagree, $6=$ Disagree, $7=$ Strongly Disagree 
preparation as the last category of the characteristics of effective English lecturers. The category, which includes item 37-item 42, depicts how well the English lecturers organize and prepare for their delivery. The first item showed that the learners (61.5\%) found their lecturers prepared for a lesson appropriately. A smaller number of learners $(5.8 \%)$ did not agree that their classes were well prepared. In line with the first item, the second item in this category depicted the lecturers providing a syllabus including course contents a long time before the lectures began (57\%). Some learners (9.6\%) were not sure that they could understand the syllabus. However, more learners $(46.2 \%)$ could not follow any of the instructional methods utilized in the classroom. As stated in item 40, the learners (46.2\%) believed that they understood the lesson objectives well. An interesting item to note was that the lecturers followed the syllabus (53.8\%) during the lesson. They also created their own supplemental materials (63.5\%).

As for the mean scores, the lowest mean was "make their own supplemental material" (M= 2.52 \& $\mathrm{SD}=1.407$ ). Supplemental materials were considered proper sources of learning. The lecturers could adjust the materials to their learners' English levels. Another lowest score $(\mathrm{M}=3.23 \& \mathrm{SD}=1.113)$ was providing a syllabus and its contents for the learners before they began learning. Both were positive characteristics viewed by the learners.

\section{Significant differences between male and female EFL learners}

TThe following tables are the results of independent t-tests for each category: Rapport, Delivery, Fairness,
Knowledge and Credibility, and Organization and Preparation.

Having completed an independent t-test, the results of Table 6 showed that there was no significant differences $(0.094>0.05)$ between male and female learners' views toward the rapport category for effective English lecturers. The views on the characteristics of effective English lecturers between male and female EFL learners were somewhat similar when considering rapport.

Table 7 depicts no significant differences between male and female EFL learners in determining the characteristics of effective English lecturers (0.668 > $0.05)$. It can be concluded that male learners' views are somewhat similar to female learners' viewson the characteristics of EFL lecturers regarding delivery.

The results of an independent t-test depicted that no significant differences $(0.653>0.05)$ were identified between male and female EFL learners in viewing the characteristics of effective English lecturers in terms of fairness. It can be said that male learners' responses were not different from female learners' responses towards the characteristics of effective English lecturers regarding fairness.

Having conducted an independent t-test, it was found that the values of equal variances assumed $(0,951>0,05)$. No significant differences were found between male and female learners' views on the knowledge and credibility characteristics of effective English lecturers.

Having finished the independent t-test, the result revealed that no significant differences were identified between male and female learners in viewing the organization and preparation of effective English

Table 6

Independent t-test of the Rapport category

\begin{tabular}{lcccccccc}
\hline & \multicolumn{1}{c}{$\begin{array}{c}\text { Levene's Test } \\
\text { for Equality of } \\
\text { Variances }\end{array}$} & & & & t-test for Equality of Means \\
\cline { 2 - 9 } & & $\mathbf{f}$ & Sig. & t & df & $\begin{array}{c}\text { Sig. } \\
\text { (2-tailed) }\end{array}$ & $\begin{array}{c}\text { Mean } \\
\text { Difference }\end{array}$ & $\begin{array}{c}\text { Std. Error } \\
\text { Difference }\end{array}$ \\
\hline Equal variances assumed & 2.918 & .094 & 1.054 & 50 & .297 & 1.630 & 1.546 \\
Equal variances not assumed & & & .988 & 33.456 & .330 & 1.630 & 1.650 \\
\hline
\end{tabular}

Table 7

Independent $t$-test of the Delivery category

\begin{tabular}{|c|c|c|c|c|c|c|c|}
\hline & \multicolumn{2}{|c|}{$\begin{array}{c}\text { Levene's Test } \\
\text { for Equality of } \\
\text { Variances } \\
\end{array}$} & \multicolumn{5}{|c|}{ t-test for Equality of Means } \\
\hline & $\mathbf{f}$ & Sig. & $\mathbf{t}$ & df & $\begin{array}{c}\text { Sig. } \\
\text { (2-tailed) }\end{array}$ & $\begin{array}{c}\text { Mean } \\
\text { Difference } \\
\end{array}$ & $\begin{array}{c}\text { Std. Error } \\
\text { Difference }\end{array}$ \\
\hline Equal variances assumed & .187 & .668 & 1.278 & 50 & .207 & 2.245 & 1.757 \\
\hline Equal variances not assumed & & & 1.255 & 42.148 & .217 & 2.245 & 1.790 \\
\hline
\end{tabular}


Table 9

Independent t-test of the Knowledge and Credibility category

\begin{tabular}{|c|c|c|c|c|c|c|c|}
\hline & \multicolumn{2}{|c|}{$\begin{array}{c}\text { Levene's Test } \\
\text { for Equality of } \\
\text { Variances }\end{array}$} & \multicolumn{5}{|c|}{ t-test for Equality of Means } \\
\hline & $\mathbf{f}$ & Sig. & $\mathbf{t}$ & df & $\begin{array}{c}\text { Sig. } \\
\text { (2-tailed) }\end{array}$ & $\begin{array}{c}\text { Mean } \\
\text { Difference }\end{array}$ & $\begin{array}{l}\text { Std. Error } \\
\text { Difference }\end{array}$ \\
\hline Equal variances assumed & .004 & .951 & -.568 & 50 & .573 & -.303 & .534 \\
\hline Equal variances not assumed & & & -.569 & 45.796 & .572 & -.303 & .532 \\
\hline
\end{tabular}

Table 10

Independent t-test of the Organization and Preparation category

\begin{tabular}{|c|c|c|c|c|c|c|c|}
\hline & \multicolumn{2}{|c|}{$\begin{array}{c}\text { Levene's Test } \\
\text { for Equality of } \\
\text { Variances } \\
\end{array}$} & \multicolumn{5}{|c|}{ t-test for Equality of Means } \\
\hline & $\mathbf{f}$ & Sig. & $\mathbf{t}$ & df & $\begin{array}{c}\text { Sig. } \\
\text { (2-tailed) }\end{array}$ & $\begin{array}{c}\text { Mean } \\
\text { Difference } \\
\end{array}$ & $\begin{array}{l}\text { Std. Error } \\
\text { Difference }\end{array}$ \\
\hline Equal variances assumed & 1.956 & .168 & .049 & 50 & .961 & .045 & .935 \\
\hline Equal variances not assumed & & & .047 & 40.098 & .963 & .045 & .963 \\
\hline
\end{tabular}

lecturers. To verify this, the result of equal variances assumed was high $(0.168>0.05)$.

\section{Discussion}

The present study revealed attributes of effective English lecturers in the Indonesian context. As for the first category, Rapport, several important characteristics or attributes were found. The attributes were friendliness, personal experiences, positive attitudes, awareness, and sense of humour. This is in line with previous studies that identified friendliness as one of the characteristics of ideal teachers and effective teaching (Feldman, 1976; Kotsoulis, 2003). Arikan, Taşer and Saraç-Süzer (2008) stresses the power of a good relationship between teachers and learners. Some students' positive attitudes toward disciplines can enable a teacher's effectiveness regarding classroom management (Zheng, 2011). Such attitudes and beliefs on teaching are paramount if compared with some common profiles of a teacher (Campbell, Kyriakides, Muijs, \& Robinson, 2004). To do that, there is aneed for more experiences, support, and intelliegence (Guskey, 1986). An effective teacher also needs to have a sense of humour (Calabria, 1960; Malikow, 2006) and use it during delivery.

As for the Delivery category, the study depicted several important attributes or characteristics as being important. This includes lecturers' enthusiasm, good examples, writing correction, speaking correction, grammar focus, group work, encouragement, and easy words. Previous studies also found that effective language teachers have enthusiasm for teaching their learners (Witcher, Onwuegbuzie, \& Minor, 2001; Malikow, 2006) and motivate and encourage learners (Feldman, 1988; Brosh, 1996; Cruickshank, Jenkins, \& Metcalf, 2003).

The attributes or characteristics of the Fairness category were fair treatment and a requirement of hard work. These two attributes were selected by the learners among five attributes. The learners did not rank the other three attributes highly as they reported that they never experienced such characteristics from their lecturers. The importance of the attributes in the Fairness category has been proved in several previous studies. A study by Brosh (1996) found that one characteristic of an effective language teacher is treating learners fairly. Brown (2001) focused on individual attributes of an effective language teacher such as flexibility or fairness.

Furthermore, Knowledge and Credibility as the fourth category consisted of two identified attributes of effective language lecturers: proficiency and knowledge. A number of studies have found that the characteristics of an effective teacher include mastery of a subject matter or field knowledge (Calabria, 1960; Shishavan \& Sadeghi , 2009; Arikan, 2010), knowledge and professional skills (Pettis, 1997), as well as proficiency and knowledge in English as the target language (Brosh, 1996; Park \& Lee, 2006).

The last category, Organization and Preparation, showed several other characteristics of effective English lecturers. They are prepared for their lectures, providing detailed course contents, having clear lesson objectives, and making supplemental materials. Every lecturer is expected to prepare for their course properly. Studies found the attributes of effective English teachers include standards, control, discipline 
(Calabria, 1960), being well organized (Brown, 2001), being flexible (Fettis, 1997), the ability to organize (Brosh, 1996), and procedural knowledge (teachers' own practical knowledge of what steps and techniques have worked well in the past) (Walls, Nardi, VonMinden, Hoffman, 2002).

\section{Conclusion}

TVarious attributes or characteristics of effective English lecturers were identified in this study. The attributes of the Rapport category are friendliness, good relationships, personal experiences, positive attitudes, awareness, and a sense of humour. As for the attributes of the Delivery category, they include enthusiasm, clarity, correction, grammar focus, group work, and encouragement. The attributes of the Fairness category are fair treatment and work requirements. The attributes of the Knowledge and Credibility category are proficiency and knowledge. The attributes of Organization and Preparation are preparation, clarity, and supplemental materials. Based on the data analysis, no significant differences were identified between male and female EFL learners in determining the attributes of effective EFL lecturers.

\section{References}

Anderson, L. M., Evertson, C. M. and Brophy, J. E. (1979). An experimental study of effective teaching in first-grade reading groups. The Elementary School Journal, 79(4), 193-223.

Arıkan, A., Taşer, D., \& Saraç-Süzer, H. S. (2008). The effective English language teacher from the perspectives of Turkish preparatory school students. Education and Science, 33(150), 42-51.

Arıkan, A. (2010). Effective English language teacher from the perspectives of prospective and in-service teachers in Turkey. Electronic Journal of Social Sciences, 9(31), 209-223.

Barnes, B. D. (2008). Perceptions of students from a Korean university about the attributes of effective lecturers of English as a foreign language (Unpublished doctoral dissertation). Edith Cowan University, Perth, Western Australia.

Brosh, H. (1996). Perceived characteristics of an effective language teacher. Foreign Language Annals, 29(2), 25-38.

Brown, H. D. (2001). Teaching by principles: An interactive approach to language pedagogy. New York, NY: Pearson Education.

Calabria, F. M. (1960). Characteristics of effective teachers. Educational Research Bulletin, 39(4), 92100.

Campbell, J., Kyriakides, L., Muijs, D., \& Robinson, W. (2004). Assessing teacher effectiveness. New York, NY: Routledge Falmer.

Canagarajah, A. S. (1999). Interrogating the "native speaker fallacy;" Non-linguistic roots, nonpedagogical results. In G. Braine (Ed.), Non-native educators in English language teaching (pp. 77-92). Mahwah, N.J.: Lawrence Erlbaum.

Chen, Y.-J. and Lin, S.-C. (2009). Exploring characteristics for effective EFL teachers from the perceptions of junior high school students in Tainan. STUT Journal of Humanities and Social Sciences, 2, 219-249.

Cruickshank, D. R., Jenkins, D. B., \& Metcalf, K. K. (2003). The act of teaching. New York, NY: McGrawHill.

Dörnyei, Z. (2007). Research methods in applied linguistics. New York, NY: Oxford University Press.

Faranda, W. T., \& Clarke I. (2004). Student observations of outstanding teaching: Implications for marketing educators. Journal of Marketing Education, 26(3), 271-281.

Feldman, K. A. (1976). The superior college teacher from the students' view. Research in Higher Education, 5(3), 243-288.

Feldman, K. A. (1988). Effective college teaching from the students' and faculty's view: Matched or mismatched priorities? Research in Higher Education, 28(4), 291-344.

Gao, M., \& Liu, Q. (2013). Personality traits of effective teachers represented in the narratives of American and Chinese preservice teachers: A cross-cultural comparison. International Journal of Humanities and Social Science, 3(2), 84-95.

Glass, G. V., \& Hopkins, K. D. (1984). Statistical methods in Education and Psychology (2nd ed.). Englewood Cliffs, NJ: Prentice-Hall.

Guskey, T. R. (1986). Staff development and the process of teacher change. Educational Researcher, 15 (5), 5-12.

Koc, E. M. (2012). Affective characteristics and teaching skills of English language teachers: Comparing perceptions of elementary, secondary and high school students. Creative Education, 4(2), 117-123.

Koutsoulis, M. (2003). The characteristics of the effective teacher in Cyprus public high school: The students' perspective. Arlington, VA: American Association of School Administrators.

Malikow, M. (2006). Effective teacher study. National Forum of Teacher Education Journal, 16(3), 1-9.

Park, G. P. \& Lee, H. W. (2006). The characteristics of effective English teachers as perceived by high school teachers and students in Korea. Asia Pacific Education Review, 7(2), 236-248. 
Pettis, J. (1997). Developing our professional competence; Some reflections. TESL Canada Journal, 16(2), 67-71.

Robson, C. (1993). Real World Research: A Resource for Social Scientists and Practitioners-Researchers. London, UK: Blackwell.

Senior, R. M.(2006). The experience of language teaching. Cambridge, UK: Cambridge University Press.

Shishavan, H. B., \& Sadeghi, K. (2009). Characteristics of an effective English language teacher as perceived by Iranian teachers and learners of English. English Language Teaching, 2(4), 130-143.

Walls, R. T., Nardi, A. H., Von Minden, A. M., \& Hoffman, N. (Winter, 2002). The characteristics of effective and ineffective teachers. Teacher Education Quarterly,29(1),39-48, .

Wichadee, S. (2010). Defining the effective English language teacher: Students' and teachers' perspectives. In A. M. Stoke (ed.), JALT 2009 Conference Proceedings (pp. 27-35). Tokyo, Japan: JALT.

Witcher, A. E., Onwuegbuzie, A. J., \& Minor L. C. (2001). Chrematistics of effective teachers: Perceptions of pre-service teachers. Research in the Schools, 8(2) 45-57.

Yilmaz, A. (2011). Quality problem in teaching profession: Qualities teacher candidates feel to be required of teachers. Educational Research and Reviews, 6(14), 812-823.

Zheng, J. F. (2011). A case study in Hsinchu area: the relations between class management effectiveness, classroom ambience and positive discipline (Unpublished Master's dissertation). University of Hsinchu, Taiwan. 